\title{
Average Time Taken in Different Groups of Cattle under Various Activities at SKN COA, Dairy Farm, Jaipur, Rajasthan, India
}

\author{
Rashmi Bhinda $^{1}$, R.P. Jat ${ }^{1}$, Bajarang Lal Choudhary ${ }^{2 *}$ and Basant Kumar Bhinchhar ${ }^{2}$ \\ ${ }^{1}$ Department of Livestock Production Management, SKNAU, Jobner, Jaipur, India \\ ${ }^{2}$ Department of Animal Husbandry and Dairying, IAS, BHU, Varanasi, India \\ *Corresponding author
}

\section{A B S T R A C T}

The present study was planned to evaluate the labour utilization pattern in management of various categories of cattle on different dairy farms. The study was conducted from $16^{\text {th }}$ November, 2015 to $13^{\text {th }}$ February, 2016 at SKN COA, dairy farm, Jobner. The observations for the daily routine work on the farm (excluding milking operations) were recorded for a period of 90 days. Milking operations were observed and noted for a period of 60 days, during the above duration. The result of experiment as the data collected during the experiment was subjected to standard methods of statistical analysis. An investigation was conducted to study the labour utilization pattern in management of various categories of cattle on different dairy farms. Animals were divided in 6 groups i.e. Milch $\left(\mathrm{G}_{1}\right)$, Pregnant $\left(\mathrm{G}_{2}\right)$, Dry animal $\left(\mathrm{G}_{3}\right)$, Calves $\left(\mathrm{G}_{4}\right)$, Heifers $\left(\mathrm{G}_{5}\right)$ and Bull and Bullock $\left(\mathrm{G}_{6}\right)$ which taken time for milking, cleaning, feeding and miscellaneous works. The average time taken in milking operation was $16.51 \pm 0.076 \mathrm{~min} / \mathrm{milch}$ animal/day. The milking operation accounted for $41.07 \%$ of the total labour requirement. The average time taken for washing of animals and cleaning of sheds of $\mathrm{G}_{1}, \mathrm{G}_{2}, \mathrm{G}_{3}, \mathrm{G}_{4}, \mathrm{G}_{5}$ and $\mathrm{G}_{6}$ groups at SKN COA dairy farm was $10.71 \pm 0.062,8.88 \pm 0.076,8.00 \pm 0.080,7.75 \pm 0.079,9.75 \pm 0.075$ and $9.45 \pm 0.069$ $\mathrm{min} /$ animal/day, respectively. The cleaning operation accounted for $22.63 \%$ of the total labour requirement in all groups. The average time taken for feeding and watering of $\mathrm{G}_{1}$, $\mathrm{G}_{2}, \mathrm{G}_{3}, \mathrm{G}_{4}, \mathrm{G}_{5}$ and $\mathrm{G}_{6}$ groups was $12.18 \pm 0.061,9.05 \pm 0.078,8.05 \pm 0.071,8.79 \pm 0.072$, $11.75 \pm 0.063$ and $9.98 \pm 0.058 \mathrm{~min} / \mathrm{animal} / \mathrm{day}$, respectively. The average time taken for miscellaneous operations in $\mathrm{G}_{1}, \mathrm{G}_{2}, \mathrm{G}_{3}, \mathrm{G}_{4}, \mathrm{G}_{5}$ and $\mathrm{G}_{6}$ groups was 1.68 $\pm 0.281,9.63 \pm 0.090$, $3.80 \pm 0.073,1.06 \pm 0.206,1.80 \pm 0.320$, and $9.84 \pm 0.199 \mathrm{~min} / \mathrm{animal} /$ day, respectively. The value analysis shows that total working time taken in $G_{1}, G_{2}, G_{3}, G_{4}, G_{5}$ and $G_{6}$ groups was $312.20,82.68,79.38,146.90,143.77$ and $87.85 \mathrm{~min} /$ labour/day, respectively.

\section{Introduction}

Management plays an important role in maintaining health and particularly growth in the cattle and buffalo. Livestock sector is an important sub-sector of the agriculture of Indian economy. It forms an important livelihood activity for most of the farmers, supporting agriculture in the form of critical inputs, contributing to the health and nutrition of the household, supplementing incomes, offering employment opportunities, and finally being a dependable "bank on hooves" in times of need. The total bovine population is 299.90 million which accounts for 58.57 percent of the total livestock (512.05 million) 
in the country. Out of total bovines, cattle account for 190.90 million (Anonymous, 2012). Livestock production offers an avenue for food security oriented self-employment to unemployment youths and women. The labour requirement of dairy farm depends upon various management activities conduct at the farm. Labour cost comes next to the feed cost for management of dairy farm, hence, greater the labour efficiency, larger is the returns from dairying. In our country, labour is either under-utilized or over-utilized thus organization or management of this resource influences proper utilization of money and material invested in dairy farming (Legha et al., 2000).

Effective utilization of man power along with other inputs is a must to increase the productivity and profitability of dairy farming. So a good role is "Make the plan to fit the man." Cost of milk production depends upon efficient utilization of man power, reduction of feed cost etc. Milking, feeding and cleaning are most labour oriented operations at a dairy farm. The time study is fundamentally aimed to draw scientific conclusions which are always better than layman's experience. With this study, efficiency of the labour utilization may be increased to a considerable extent. Standard norms for labour requirements for different dairy farm operations are available. Some old studies by Rawat et al., (1973), Singh and Dave (1985) and Devarajulu and Naidu (1989) on dairy farm work analysis may not fit into present day context because of revision of wages and labour laws. Information on labour input for carrying out day to day operations at dairy farm viz. milking, feeding, cleaning of shed, washing, and miscellaneous work and also on factors influencing the same is scanty (Grewal and Rangi, 1980). Hence, it is required to estimate the time requirement for various dairy farm operations for different categories of animals for efficient utilization of man power.

\section{Materials and Methods}

\section{Location}

The present study on labour utilization pattern in management of various categories of cattle on different dairy farms was carried out at S.K.N. College of Agriculture, dairy farm Jobner (H.Q.), Phulera Tehsil, Agrim dairy farm, in Jaipur district of Rajasthan state. Geographically Jobner is located at 45.0 k.m. west of Jaipur at $26^{\circ} 05^{\prime}$ North latitude $75^{\circ} 28^{\prime}$ East longitudes and at an altitude of 427 meter above sea level.

\section{Plan of work}

The entire farm had similar management during the study period. The system of housing and type of labour as well as all managemental practices were similar at three selected dairy farms.

\section{Period of study}

The study was conducted from $16^{\text {th }}$ November, 2015 to $13^{\text {th }}$ February, 2016. The observations for the daily routine work on the farm (excluding milking operations) were recorded for a period of 90 days. Milking and associated operations were observed and noted for a period of 60 days, during the above duration.

\section{Animals used in the study}

The study was conducted on the Labour utilization pattern in management of various categories of cattle. All six categories of animals were present at selected dairy farms and selection of different breeds for comparison of labour utilization pattern among the breeds. Animals were divided in 6 groups i.e. Milch $\left(\mathrm{G}_{1}\right)$, Pregnant $\left(\mathrm{G}_{2}\right)$, Dry animal $\left(\mathrm{G}_{3}\right)$, Calves $\left(\mathrm{G}_{4}\right)$, Heifers $\left(\mathrm{G}_{5}\right)$ and Bull and Bullock $\left(\mathrm{G}_{6}\right)$. The time taken for milking, cleaning, feeding and miscellaneous 
works was recorded. During the study period, the average effective herd strength of different dairy farms is given in table 1 .

\section{Housing of the animals}

The housing system adopted at different dairy farms was loose housing as well as conventional barn. The layout of the dairy farm is given (Table 1).

\section{Number of labourers involved}

Labour required for smooth running of dairy farms. Two types of labour:-

(i) Skilled labour were working specific work i.e. farm mechanism and milking etc.

(ii) Unskilled labours were working normal work i.e. cleaning, harvesting etc.

Engaging two types of labour, temporary and permanent as well as male and female, the one labour unit was calculated as one adult unit. Labour resources are of two kinds fixed and variable. Fixed labour is labour, which is used on farm throughout the year, it includes both permanent workers and family labour.

Variable labour is labour used on seasonal basis, i.e. casual labour that can be hired when needed. The labour strength was 10 , at SKN COA, dairy farm, but average daily present of working labour was 6 out of 10 at SKN COA dairy farm due to $\mathrm{GH}$, Leave and CCL as per govt. rules. The strength of labour is described in tables 2 and 3 .

\section{Daily operation schedule}

The various activities are carried out on the dairy farms routinely (daily or periodically), there should be well planned and carried out punctually. It is ideal to draw up a schedule of dairy farm operations performed for each farm so that the personnel working on farm can carry out various operations at regular timing. A model of such schedule is given in table 4 .

\section{Recording of time taken for various activities}

The data were recorded without disturbing the normal ongoing routine activities of the farm. The labours engaged in the livestock farm activities were also not conscious about the recording of data.

The study was carried out on different groups of animals, which were basically categorized according to their age or status of animals. These animals were maintained in different sheds of the farm according to their groups.

The animals were divided into six groups. The various operations performed were milking, washing the animals, cleaning the shed, feeding, watering and miscellaneous works. The miscellaneous works included deworming, vaccination, dehorning, A.I and treatment of animals. In case of bulls grooming the skin, exercise and servicing were also included.

\section{Milking operation}

The milking was done manually and machine milking in two shifts as morning and evening. Cows were milked twice a day at 4.00 A.M. and 4.00 P.M. in the milking parlour. $60 \%$ of cows were milked by hand and $40 \%$ by machine. Time was recorded both for hand milking and machine milking of cows.

\section{Animal tying and release time}

The time (minutes) spent for tying and releasing of animal in the milking shed was recorded. 
Calf handling during milking and milk suckling by calf

The time (minutes) taken by the calf to suckle its dam before milking, time spent for washing of udder, time spent for bringing calf from calf pen to its dam in the milking barn and taking back to calf pen after suckling were recorded.

\section{Attachment and detachment of milking machine}

The time (minutes) spent for attaching and detaching the milking machine cluster to the individual teats of the cow was recorded (during machine milking).

\section{Actual milking time per milking}

The time (minutes) spent for complete milking of the animals for both by hand and machine milking was recorded.

\section{Weighing the milk, loading and unloading} milk can

The time (minutes) spent in weighing the milk, loading the milk filled cans and unloading the empty milk cans from the vehicle was recorded.

\section{Washing of milking machine and cleaning of can}

The time (minutes) spent for washing of milking machine and cleaning of can was recorded.

\section{Cleaning and washing of shed}

The time (minutes) spent in removal of dung, left over refusal and cleaning the floor of the shed as well as time spent for grooming and washing of animals was recorded. The collection and lifting of dung and agricultural refuge was basically done manually with a shovel. Broom sticks/water spraying was used for the cleaning operation.

\section{Feeding of the animals}

Feeding time (minutes) was recorded as the time spent for distribution of concentrate, green and dry fodder to various categories of animals in different sheds.

\section{Miscellaneous works}

The time (minutes) spent for the miscellaneous work viz. treatment, deworming, A.I. and vaccination was noted.

\section{Total working time}

Total working time was deduced by adding the time taken for various activities as indicated above. For milch animals, time taken for milking operation was also included in the total time. Based on the total time spent on each operation and for different categories of animals, number of man-minutes /animal/day for each operation was calculated.

\section{Be manage by one labour unit}

The compute time taken for carrying out different activities and various categories of animal can be managed by one labour unit/a.u./day. The man power received was evaluated on a unit basis.

\section{Statistical analysis}

The data obtained from the study was analyzed by using statistical tools as per the procedure laid down by (Snedkar et al., 1994). The different statistical tools such as mean, standard error (SE) and coefficient of variance $(\mathrm{CV})$ were worked out to compare the data and interpret the results. Data was 
analyzed dairy wise, category wise in overall and compare of means by using statistical tool as simple tabular analysis, average, percentage and coefficient of variance $(\mathrm{CV})$ as and wherever necessary.

\section{Results and Discussion}

The present study was planned to evaluate the labour utilization pattern in management of various categories of cattle on different dairy farms. The study was conducted from $16^{\text {th }}$ November, 2015 to $13^{\text {th }}$ February, 2016 at SKN COA, dairy farm, Jobner. The observations for the daily routine work on the farm (excluding milking operations) were recorded for a period of 90 days. Milking operations were observed and noted for a period of 60 days, during the above duration. The result of experiment as the data collected during the experiment was subjected to standard methods of statistical analysis

\section{Milking operation}

The Average time taken in milking operation at SKN COA, dairy farm is presented in table 5. The average time taken in milking operation was $16.51 \pm 0.076 \mathrm{~min} / \mathrm{milch}$ animal/day. The milking operation accounted for $41.07 \%$ of the total labour requirement. These findings are in agreement with those observed by (Brien et al., 2007). However, (Devarajulu et al., 1989) observed that milking operation took about $30 \%$ of total time. The variations may be due to various factors of milking operations. The maximum time spent in milking operation than other activities might be due to combination of various activities i.e. handling of animal during milking, calf handling at milking, weighing and distribution of milk and method and interval of milking twice a day as well as time taken for tying on hind legs by anticow kicker, wiping the udder, stimulating the udder, taking out first strip, actual milking time etc. for hand milking.

\section{Cleaning of sheds and washing of animals}

The average time taken for washing of animals and cleaning of sheds in different groups at SKN COA dairy farm is also presented in table 5. The average time taken for washing of animals and cleaning of sheds of $G_{1}, G_{2}, G_{3}, G_{4}, G_{5}$ and $G_{6}$ groups at SKN COA dairy farm was 10.71 \pm 0.062 , $8.88 \pm 0.076, \quad 8.00 \pm 0.080, \quad 7.75 \pm 0.079$, $9.75 \pm 0.075$ and $9.45 \pm 0.069 \mathrm{~min} / \mathrm{animal} / \mathrm{day}$, respectively. The cleaning operation accounted for $22.63 \%$ of the total labour requirement in all groups. Milch animals required more time for washing, while pregnant animals required less time. This is because for clean milk production, all body parts of animal are washed thoroughly. Heifers required more time for washing while calves required less time. This may be due to the difference in the size of the shed and extra care of breed able heifers. Similar findings were reported by (Sreedhar et al., 2009). However, (Grewal et al., 1980) observed that Sweeping of the animal shed and cleaning of animals accounted for $14-16 \%$ of the total labour requirement.

\section{Feeding and watering of animals}

The average time taken for feeding and watering in different groups at SKN COA, dairy farm is presented in table 5. The average time taken for feeding and watering of $\mathrm{G}_{1}, \mathrm{G}_{2}$, $\mathrm{G}_{3}, \mathrm{G}_{4}, \mathrm{G}_{5}$ and $\mathrm{G}_{6}$ groups was $12.18 \pm 0.061$, $9.05 \pm 0.078, \quad 8.05 \pm 0.071, \quad 8.79 \pm 0.072$, $11.75 \pm 0.063$ and $9.98 \pm 0.058 \mathrm{~min} / \mathrm{animal} /$ day, respectively.

The feeding and watering operations required $24.78 \%$ of the total labour at the farm. Feeding requires more working time next to milking; similar findings were reported by (Sathiyabarathi et al., 2015). However, (Whipp, 1976) observed that feeding activities accounted for $16 \%$ of total time. 
Feeding of milch animals took more time than other categories of animals which might be due to the additional work involved in socking of concentrate mixture two times prior to milking.

Feeding time next to milch animal was in heifer group due to more care and extra work was involved for achieving the age of first calving (AFC) which may increase the economic life of animals.

\section{Miscellaneous works}

The average time taken for miscellaneous operations in different groups at SKN COA, dairy farm is presented in table 5. The average time taken for miscellaneous operations in $G_{1}$, $\mathrm{G}_{2}, \mathrm{G}_{3}, \mathrm{G}_{4}, \mathrm{G}_{5}$ and $\mathrm{G}_{6}$ groups was $1.68 \pm 0.281$, $9.63 \pm 0.090, \quad 3.80 \pm 0.073, \quad 1.06 \pm 0.206$, $1.80 \pm 0.320$, and $9.84 \pm 0.199 \mathrm{~min} / \mathrm{animal} /$ day, respectively. The miscellaneous operations accounted for $11.52 \%$ of the total labour requirement.

Table.1 Herd strength of various categories of animals at different dairy farms

\begin{tabular}{llc}
\hline Groups & $\begin{array}{l}\text { Categories of } \\
\text { animals }\end{array}$ & $\begin{array}{c}\text { S.K.N Dairy } \\
\text { Farm } \\
\text { (Cross bred) }\end{array}$ \\
\hline $\mathrm{G}_{1}$ & Milch & 15 \\
$\mathrm{G}_{2}$ & Pregnant & 03 \\
$\mathrm{G}_{3}$ & Dry & 02 \\
$\mathrm{G}_{4}$ & Calves & 04 \\
$\mathrm{G}_{5}$ & Heifers & 06 \\
$\mathrm{G}_{6}$ & Bulls \& Bullock & 03 \\
\hline & Total & $\mathbf{3 3}$ \\
\hline
\end{tabular}

Table.2 Categories of animals and daily working labour at different dairy farms

\begin{tabular}{llc}
\hline Group & Categories of animal & No. of labour working in groups \\
\cline { 3 - 3 } & & SKN \\
\hline $\mathrm{G}_{1}$ & Milch cows & 2.0 \\
$\mathrm{G}_{2}$ & Pregnant cows & 1.0 \\
$\mathrm{G}_{3}$ & Dry & 0.5 \\
$\mathrm{G}_{4}$ & Calves & 0.5 \\
$\mathrm{G}_{5}$ & Heifers & 1.0 \\
$\mathrm{G}_{6}$ & Bulls and Bullock & 1.0 \\
\hline \multicolumn{2}{c}{ Total daily working labour } & 6.0 \\
\hline
\end{tabular}

Table.3 Type of labour at different dairy farms

\begin{tabular}{lccc}
\hline \multirow{2}{*}{$\begin{array}{l}\text { Type } \\
\text { Labour }\end{array}$} & of & \multicolumn{3}{c}{ S.K.N dairy farm } \\
\cline { 2 - 4 } & Male & Female & Total \\
\hline Permanent & 09 & - & 09 \\
Temporary & 01 & - & 01 \\
Total & 10 & - & 10 \\
\hline
\end{tabular}


Int.J.Curr.Microbiol.App.Sci (2017) 6(8): 1830-1838

Table.4 Schedule of day-to-day operations on dairy farms

\begin{tabular}{|c|c|}
\hline Time (hours) & Farm operations \\
\hline $3.30-4.00$ & 1.Cleaning of feed manger and removal of cow dung \\
\hline & $\begin{array}{l}\text { 2. Feeding of dry fodder to milch cows } \\
\text { 3. Feeding concentrate ration just before milking }\end{array}$ \\
\hline $4.00-5.00$ & 2. Milking cows and weighing of milk of individual cow \\
\hline $5.00-5.30$ & 1. Distribution of the milk (in cans) \\
\hline $5.30-8.00$ & $\begin{array}{l}\text { 1. Releasing milch stock to loose house } \\
\text { 2. Cleaning of shed } \\
\text { 3. Feeding of dry fodder to dry and pregnant stock } \\
\text { 4. Washing and disinfection of milking barns }\end{array}$ \\
\hline $8.00-12.00$ & $\begin{array}{l}\text { 1. Cleaning of calf, dry stock, bullock and bull sheds } \\
\text { 2.Tying of milch stock } \\
\text { 3. Feeding concentrate ration to all category of animals } \\
\text { 4. Exercising and grooming of bulls }\end{array}$ \\
\hline $12.00-13.00$ & 1. Lunch cum rest period for labourers \\
\hline $13.00-15.00$ & $\begin{array}{l}\text { 1. Feeding concentrate to milch stock } \\
\text { 2. Removal of cow dung and cleaning of sheds } \\
\text { 3. Washing of milch stock }\end{array}$ \\
\hline $15.30-17.00$ & $\begin{array}{l}\text { 1. Feeding the other half of daily concentrate ration } \\
\text { to milch cows just before milking } \\
\text { 2. Milking and weighing of milk of individual cow }\end{array}$ \\
\hline $17.00-18.30$ & $\begin{array}{l}\text { 1 Distribution of the milk (in cans) } \\
\text { 2. Washing and disinfection of can and milking room }\end{array}$ \\
\hline $18.30-3.30$ & 1. Night watchman duty \\
\hline
\end{tabular}

Table.5 Average time (min/animal/day) taken in different groups under various activities at SKN COA, dairy farm $($ Mean \pm SE)

\begin{tabular}{|c|c|c|c|c|c|c|c|c|c|}
\hline \multirow{2}{*}{ Activities } & \multicolumn{6}{|l|}{ Groups } & \multirow{2}{*}{ Total } & \multirow{2}{*}{ Average } & \multirow{2}{*}{$\begin{array}{l}\text { Per } \\
\text { cent }\end{array}$} \\
\hline & $\mathbf{G}_{1}$ & $\mathbf{G}_{2}$ & $\mathbf{G}_{\mathbf{3}}$ & $\mathbf{G}_{4}$ & $\mathbf{G}_{5}$ & $G_{6}$ & & & \\
\hline $\begin{array}{l}\text { Milking } \\
\text { operation }\end{array}$ & $\begin{array}{l}16.51 \pm 0.076 \\
(0.92)\end{array}$ & 0.00 & 0.00 & 0.00 & 0.00 & 0.00 & 16.51 & $\begin{array}{l}16.51 \pm 0.076 \\
(0.92)\end{array}$ & 41.07 \\
\hline Cleaning & $\begin{array}{l}10.71 \pm 0.062 \\
(2.25)\end{array}$ & $\begin{array}{l}08.88 \pm 0.076 \\
(3.37)\end{array}$ & $\begin{array}{l}08.00 \pm 0.080 \\
(3.89)\end{array}$ & $\begin{array}{l}07.75 \pm 0.079 \\
(3.97)\end{array}$ & $\begin{array}{l}09.75 \pm 0.075 \\
(3.02)\end{array}$ & $\begin{array}{l}09.45 \pm 0.069 \\
(2.87)\end{array}$ & 54.54 & $\begin{array}{l}09.09 \pm 0.45 \\
(12.26)\end{array}$ & 22.63 \\
\hline $\begin{array}{l}\text { Feeding \& } \\
\text { Watering }\end{array}$ & $\begin{array}{l}12.18 \pm 0.061 \\
(1.96)\end{array}$ & $\begin{array}{l}09.05 \pm 0.078 \\
(3.37)\end{array}$ & $\begin{array}{l}08.04 \pm 0.071 \\
(3.49)\end{array}$ & $\begin{array}{l}08.78 \pm 0.072 \\
(3.18)\end{array}$ & $\begin{array}{l}11.75 \pm 0.063 \\
(2.07)\end{array}$ & $\begin{array}{l}09.98 \pm 0.058 \\
(2.28)\end{array}$ & 59.78 & $\begin{array}{l}09.96 \pm 0.68 \\
(16.81)\end{array}$ & 24.78 \\
\hline Miscellaneous & $\begin{array}{l}01.68 \pm 0.281 \\
(28.90)\end{array}$ & $\begin{array}{l}09.63 \pm 0.090 \\
(3.59)\end{array}$ & $\begin{array}{l}03.80 \pm 0.073 \\
(3.34)\end{array}$ & $\begin{array}{l}01.06 \pm 0.206 \\
(33.51)\end{array}$ & $\begin{array}{l}01.80 \pm 0.320 \\
(30.69)\end{array}$ & $\begin{array}{l}09.84 \pm 0.199 \\
(3.50)\end{array}$ & 27.81 & $\begin{array}{l}04.63 \pm 1.65 \\
(87.62)\end{array}$ & 11.52 \\
\hline $\begin{array}{l}\text { Total } \\
\text { working time }\end{array}$ & 41.08 & 27.56 & 19.84 & 17.59 & 23.30 & 29.27 & 158.64 & 40.19 & 100 \\
\hline
\end{tabular}

Figures in parenthesis are represent to coefficient of variance (CV \%) 
Table.6 Average total working time (min/labour/day) taken for various activities in different groups at SKN COA dairy farm

\begin{tabular}{lllllll}
\hline Groups & $\begin{array}{l}\text { In } \\
\text { hand/machine } \\
\text { milking }\end{array}$ & Cleaning & Feeding & Miscellaneous & $\begin{array}{l}\text { Total } \\
\text { working } \\
\text { time }\end{array}$ & $\begin{array}{l}\text { Total working } \\
\text { time/labour/day }\end{array}$ \\
\hline $\mathrm{G}_{1}$ & $\begin{array}{l}247.65 \pm 0.50 \\
(5.31)\end{array}$ & $\begin{array}{l}160.70 \pm 0.93 \\
(2.25)\end{array}$ & $\begin{array}{l}190.85 \pm 1.00 \\
(2.03)\end{array}$ & $\begin{array}{l}25.2 \pm 4.21 \\
(28.92)\end{array}$ & 624.40 & $\mathbf{3 1 2 . 2 0}$ \\
& & $026.63 \pm 0.22$ & $027.16 \pm 0.24$ & $28.89 \pm 0.59$ & 082.68 & $\mathbf{0 8 2 . 6 8}$ \\
$\mathrm{G}_{2}$ & 0.00 & $(3.37)$ & $(3.49)$ & $(3.55)$ & & \\
& & $016.00 \pm 0.15$ & $016.09 \pm 0.14$ & $07.60 \pm 0.14$ & 039.69 & $\mathbf{0 7 9 . 3 8}$ \\
$\mathrm{G}_{3}$ & 0.00 & $(3.89)$ & $(3.60)$ & $(3.34)$ & & \\
& & $031.00 \pm 0.31$ & $038.21 \pm 0.32$ & $04.24 \pm 0.82$ & 073.45 & $\mathbf{1 4 6 . 9 0}$ \\
$\mathrm{G}_{4}$ & 0.00 & $(3.97)$ & $(3.30)$ & $(33.59)$ & & \\
& & $058.52 \pm 0.45$ & $074.45 \pm 0.41$ & $10.80 \pm 1.92$ & 143.77 & $\mathbf{1 4 3 . 7 7}$ \\
$\mathrm{G}_{5}$ & 0.00 & $(3.02)$ & $(2.13)$ & $(30.73)$ & & \\
& & $028.35 \pm 0.20$ & $029.98 \pm 0.17$ & $29.52 \pm 0.59$ & 087.85 & $\mathbf{0 8 7 . 8 5}$ \\
$\mathrm{G}_{6}$ & 0.00 & $(2.87)$ & $(2.36)$ & $(3.51)$ & & \\
\hline Total & $\mathbf{2 4 7 . 6 5}$ & $\mathbf{3 2 1 . 2}$ & $\mathbf{3 7 6 . 7 4}$ & $\mathbf{1 0 6 . 2 5}$ & $\mathbf{1 0 5 1 . 8 4}$ & $\mathbf{8 5 2 . 7 8}$ \\
\hline
\end{tabular}

Figures in parenthesis are represent to coefficient of variance (CV \%)

Similar findings were reported by (Sreedhar et al., 2009) regarding miscellaneous operation for pregnant cows. It was observed that milch animals took less time for miscellaneous works whereas pregnant animals took more time which might be due to the additional care was given for their management as well as more time for bulls. Miscellaneous works constituted the major part of work for the bulls care since exercise is considered as an important aspect of management of bulls.

\section{Total working time}

The total working time in different groups at SKN COA, dairy farm is presented in table 6. The value analysis shows that total working time taken in $\mathrm{G}_{1}, \mathrm{G}_{2}, \mathrm{G}_{3}, \mathrm{G}_{4}, \mathrm{G}_{5}$ and $\mathrm{G}_{6}$ groups was 312.20, 82.68, 79.38, 146.90,
143.77 and 87.85 min/labour/day, respectively, observed that nearly $50 \%$ of total time on a dairy farm was spent in attending milch animals. This was mainly due to the additional time spent for milking and intensive care taken for management of milch animals as this group required more attention and time than other categories of animals. The average total working time (min/labour/day) taken was 247.65, 321.20, 376.74 and 106.25 in milking, cleaning, feeding and miscellaneous work, respectively.

\section{References}

Anonymous. 2012. 19 th $^{\text {th }}$ Livestock Census all India report. Ministry of Agriculture Department of Animal Husbandry, Dairying and Fisheries. Krishi Bhawan, New Delhi. 11- 23. 
Legha, R.A. and Tomar, O.S. 2000. Man power utilization in growing crossbred females under different management systems of housing and feeding. Indian J. Animal Production and Management, 16: 15-17.

Snedkar, G.W. and Cochran, W.G. 1994. Statistical method. $8^{\text {th }}$ Edn. Iowa, State University Press. Ames, Iowa.

Brien, B., Gleeson, D., Donovan, K., Ruane, D., Kinsella, J., Mee, J.F., Boyle, L. and Mc Namara, J. 2007. Labour efficiency on-farm. Project Number, 5193.

Devarajulu, D. and Narasaiah K. Naidu. 1989. Time motion studies of some dairy farm operations. Indian J. Dairy Sci., 42(3): 471- 474.

Sreedhar, S. and Ranganadham, M. 2009. Labour utilization pattern in management of various categories of dairy animals. Indian J. Animal Res., 43(3):187-190.

Grewal, S.S. and Rangi, P.S. 1980. Economics and employment of dairying in Punjab. Indian J. Agri. Economics, 35(4): 120125.

Sathiyabarathi, M., Jeyakumar, S., Manimaran, A., Jayaprakash G., Dhinesh Kumar, R., Chandrasekar, T., Arul Prakash, M., Thulasiraman Parkunan, and Santu Monda. 2015. Dairy Farm Labour Utilization Pattern and Their Welfare. Indian J. Dairy and Bio Sci., pp. 2.

Whipp, J.I. 1976. The time between milking. Dairy Sci. Abstract, 39(3): 1134.

\section{How to cite this article:}

Rashmi Bhinda, R.P. Jat, Bajarang Lal Choudhary and Basant Kumar Bhinchhar. 2017. Average Time Taken in Different Groups of Cattle under Various Activities at SKN COA, Dairy Farm, Jaipur, Rajasthan. Int.J.Curr.Microbiol.App.Sci. 6(8): 1830-1838.

doi: https://doi.org/10.20546/ijcmas.2017.608.215 